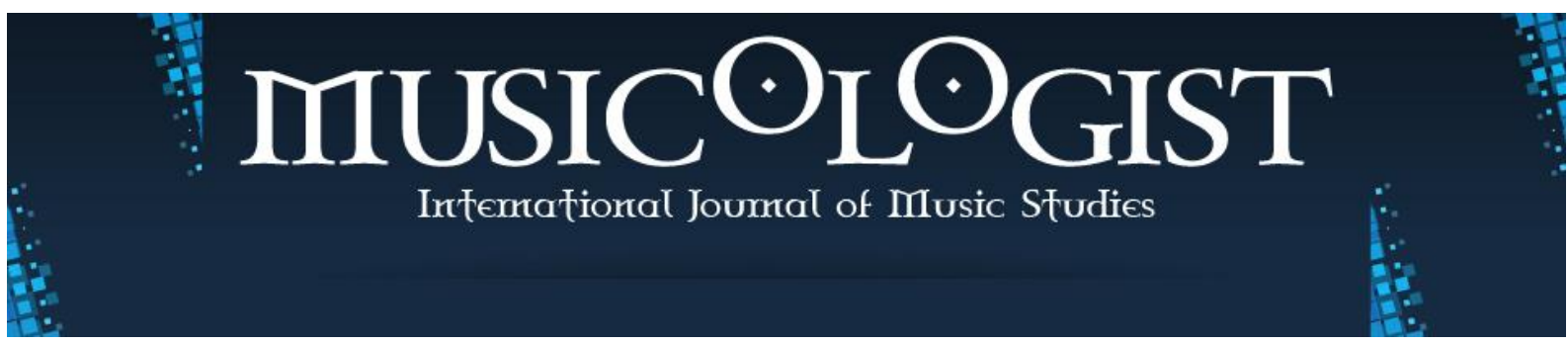

Trabzon University State Conservatory @ $2017-2021$

Volume 5 Issue 2 December 2021

Research Article

Musicologist 2021.5 (2): 107-132

DOI: $10.33906 /$ musicologist.882808

YAPRAK MELİKE UYAR

Humboldt University of Berlin, Germany

yaprakmelikeuyar@gmail.com

orcid.org/0000-0002-3830-3731

\title{
Turkish Disco: The Intersection of Anatolian Pop, Groove, and Psychedelia
}

\begin{abstract}
This article aims to examine the genre of Turkish disco, with its local and global connotations. Using the theory of glocalization, the genre will be discussed as a means to understand current dynamics in the music industry. This research is a product of a discography survey and fieldwork consisting of extended interviews with DJs and musicians who were a part of the scene.

What is labeled as disco music in Turkey, and what is referred to as 'Turkish disco' in the global music industry are, in fact, two different music cultures. The term's local usage refers to specific Turkish recordings from the late 1970s, in which various forms of Turkish art and folk music were reinterpreted, usually with Moog synthesizers. On the other hand, more recent connotations of Turkish disco owe much to DJs, and the digging, editing, and remixing culture of the 2010s. Coming hand in hand with the term Turkish psychedelic, many of these recent edits and remixes by DJs and producers were selected from the LPs and singles of the 1970s, which drew inspiration from pop, soul, folk, jazz, psychedelic rock, funk, and Anatolian pop. Thus, Turkish disco in the past decade has become an umbrella term for contemporary edits and remixes of the Turkish popular music of the 1970s. The reinterpretation of the forms such as Oyun Havası and potpori within the subheading of disco will be analyzed to understand the cultural aesthetics of taste and the political background of musical fusion.
\end{abstract}

\section{KEYWORDS}

Turkish disco

Disco

Turkish psychedelic

Popular music

Glocalization

Anatolian pop

Fusion 
Disco, as a musical genre and a dance culture that questioned the conventional boundaries of race and gender, embraced the concepts of liberation, and created its own unique anthems of fashion and style, came about in New York City's minority communities in the late 60 s and early 70 s, and turned into a global dance culture and a mainstream success. In each destination it visited, it found many layers of meaning and performance applications. In Turkey as well, localization of disco was subject to many cultural and musical connotations, so that questioning the concept of disco implicates key turning points in the history of Turkish popular music.

This article intends to examine the localization of disco music in Turkey, and the reinvention of the term 'Turkish disco' in the global music market. Using the theory of glocalization, the genre will be discussed with a comparative analysis of the local and global usages of the term. Glocalization denotes the notion of an interplay between globalization and localization that has different cultural outcomes in different regions of the world. What is labeled as disco music in Turkey and what is referred to as 'Turkish disco' in the global music industry are, in fact, two distinct music cultures. The local use of the term refers to specific Turkish recordings from the late 1970s, in which various forms of Turkish art and folk music were reinterpreted, usually with Moog synthesizers. Internationally, however, more recent connotations of Turkish disco are linked to DJs and the emergent digging, editing and remixing culture of the 2010s. Technological advancements made production techniques easily accessible for home studios, while the online and self-released music mediation opportunities contributed to the rise of DJ culture. With the movement of Retromania, "the obsession of the society with the cultural artifacts of its own immediate past" (Reynolds, 2011: 8), many DJs turned towards the past and local music traditions for inspiration. With Turkish psychedelia, many of these recent edits and remixes by DJs and producers were selected from LPs and singles of the 1970s, which drew inspiration from Anatolian pop/rock ${ }^{1}$, soul, folk, jazz, psychedelic rock, funk and Anatolian folk music of Turkey.

The rise of Turkish disco and Turkish psychedelic in the global music market owes much to the pioneering efforts of several DJs. Turkish DJ Barış K was one of the first to anticipate

\footnotetext{
${ }^{1}$ Hereinafter referred to as Anatolian pop. Although Anatolian pop and Anatolian rock can be used interchangeably in Western literature, in Turkish literature, Anatolian rock represents the second wave of Anatolian pop emerged in the late 1990s, including musicians such as Kıraç, Haluk Levent, and Ayna.
} 
the vinyl revival and localization trends in the local popular music industry. The term 'vinyl revival' refers to the updated relevancy of vinyl culture. There has been an increase in sales of vinyl records in the Western world since 2007 (Richter, 2014). As the ways we acquire music in the new millennium shifted due to the prevalence of the internet, and downloading and streaming became the dominant methods, the music industry experienced a paradigm shift as well. Discovering the musical past by digging through records and presenting these materials in the form of mixes or re-releases contributed to the utilization of local music traditions as a form of differentiation in the popular music industry.

This research is a product of a discography survey and fieldwork consisting of extended interviews with DJs and musicians who are part of this scene ${ }^{2}$. To be able to discuss the term 'Turkish disco,' I will first peruse the process of glocalization that occurred in Turkish popular music of the 1970s, with a focus on Anatolian pop. Since the aim of this piece is to examine the local and global connotations of Turkish disco, pioneering disco recordings will be reviewed. The final part of the article deals with these recent representations of Turkish disco.

\section{The 1970s in Turkey: An Era of Glocalization}

Many genres of Turkish popular music are based on both local and global influences. The idea of synthesis inherent in the musics of Turkey has its roots in historical state music policies. Since the early days of the Republic of Turkey, music was at the foreground of the proposed reforms as an important art form to represent the emerging national 'Turkish' identity. Westernization of cultural and musical practices started in the lateOttoman period, with the Tanzimat (Reorganisation) Decree of 1839 and later became significant after the declaration of the Republic, with an attempt to correlate it with the identity of the 'modern Turk'. ${ }^{3}$ The founding leader of the Republic, Mustafa Kemal Atatürk defined the national cultural agenda as a combination of European and Anatolian values. A patriotic Turk was to benefit from the scientific and technological advancements

\footnotetext{
${ }^{2}$ As an ethnomusicologist teaching the history of Turkish popular music, and a DJ of 17 years, I had the chance to observe current trends in the Turkish popular music industry. I owe much gratitude to the DJs and musicians who shared their experiences and opinions with me: Emir Özer, Görkem Karabudak, Holger Lund, İpek İpekçioğlu, Kaan Düzarat, Mehmet Aslan, Orçun Baştürk, Sertaç Oğul, and Volga Çoban.

${ }^{3}$ See Bülent Aksoy (1985), "Tanzimat'tan Cumhuriyet'e Musiki ve Batılllaşma" (Music and Westernization from the Tanzimat to the Republic).
} 
of the West while internalizing the spirituality of the East (Kadıoğlu, 1996). As a means to achieve that ideal, a synthesis of Anatolian folk and Western classical music was seen as the ideal music representing this new country that was established on the remnants of the Ottoman Empire. However, the legacy of the Ottoman Empire has been a controversial issue throughout history.

Policies fostering European music facilitated the integration of Western ballroom dance styles. In the early days of the Republic, dances such as the waltz and the foxtrot became popular among the cultural elites, who regularly visited 'State Balls' - social events that broke down the barriers between men and women in Ottoman society (Alexandrov, 2013: 178). Actually, the roots of Western-style dance culture in Turkey were venues called dansing (dance halls), in which dances such as the Charleston, foxtrot, waltz, shimmy, one step, and tango were performed. Carol Woodall mentions dansing as well as the city's streets, bars, hotels, and cinemas as the 'contact zones' of Istanbul in the 1920s, in which various ethnic groups, classes and professions, as well as emigrants and Allied occupiers, came together (2008: 40).

A surprising outcome of the Westernization idea was the evolution of jazz and tango. Tango became the first Western genre to be adopted into local culture with compositions that included Turkish lyrics. By contrast, jazz was initially used as a mere generic category that encompassed all Western popular dance styles, from ragtime to foxtrot. Armenian violinist/saxophonist Leon Avigdor introduced jazz to Turkey in the mid1920s (Mimaroğlu, 1958: 122). It took another two decades before Swing Amatör became the first genuine jazz band, and jazz gradually found its own identity from its North American origins, whereas other Western popular music styles were labelled as Turkish Light Music (Uyar \& Karahasanoğlu, 2016: 137). ${ }^{4}$

The first example of Turkish Light Music (later known as Turkish pop music) was 'Bak Bir Varmış Bir Yokmuş' (Look, Once Upon a Time) released in 1961 by the renowned jazz pianist and singer İlham Gencer. ${ }^{5}$ The lyricist and radio host Fecri Ebcioğlu wrote Turkish lyrics to French pop singer Bob Azzam's 'C'est écrit dans le ciel', becoming the pioneer of Aranjman music, a form of popular music with Turkish lyrics. The term Aranjman

\footnotetext{
4 The term "Light Music" denotes Easy Listening.

5 Unless otherwise stated, all translations are the author's.
} 
signifies arranged/cover versions of popular songs of usually French, Italian, or English origin with adapted Turkish lyrics. Aranjman was strongly supported by Turkish Radio and Television (TRT), which gave it regular airtime and labeled the new genre as Light Music with Turkish Lyrics (Türkçe Sözlü Hafif Müzik) (Tekelioğlu, 1996: 211).

The incorporation of Turkish elements into Western popular music dominated the music of the 1970s, resulting in a fusion of Turkish folk with Western popular music genres, such as pop, psychedelic and prog rock, and the resulting genre was called Anatolian pop. The label 'Anatolian pop' was coined by Taner Öngür6, the bass player of Moğollar, one of the key bands of the movement. Actually, the movement started in 1964, when the jazz singer Tülay German released her groundbreaking single, 'Burçak Tarlası' (Field of Vetch), pioneering Anatolian pop and thereby opening a new path for Turkish popular music. Produced by her partner, jazz drummer Erdem Buri, and performed by Doruk Onatkut Orchestra, it was the first traditional Turkish folk song performed with Western instruments: flute, guitar, a drumset, percussion, and string instruments. Tülay German's vocals display an operatic influence, while the raw timbre of the claves marks the rhythmic drive of the piece. This was a milestone in Turkish popular music: instead of directly imitating the genre, as had been the case with jazz, rock'n'roll and Aranjman, German's music exhibited a novel and unique theoretical and harmonic combination.

The synthesis zeitgeist of the 1970s was not just specific to Anatolian pop; jazz and funk were also adapted to local taste. In 1973, Mustafa Özkent released his LP Gençlik ile Elele (Hand in Hand for Youth) offering a unique blend of Turkish folk music and funk. Gökçen Kaynatan, with his exquisite style fusing electronics with local influences, is referred to as one of the pioneers of electronic music within the borders of Turkey. ${ }^{7}$ In 1978, the first Turkish jazz album, Jazz Semai, was released by Erol Pekcan (drums), Tuna Ötenel (saxophone and piano), and Kudret Öztoprak (bass). This was the first jazz LP recorded and released by local musicians, and the first recording incorporating tonal materials, rhythmic structures, forms, or repertoire samples from Turkish music into jazz. All these attempts reveal the complex nature of the aesthetics of taste, which I intent to explain through the concept of glocalization.

\footnotetext{
${ }^{6}$ See Taner Öngür. (2018). [Liner notes]. In Sayko Ana. Digital Album. Istanbul: Tantana Records.

7 İlhan Mimaroğlu and Bülent Arel were pioneering Turkish composers of electronic art music, but their activities were based in USA.
} 
Roland Robertson defined glocalization as "the simultaneous promotion of what is, in one sense, standardized product, for particular markets, in particular flavors, and so on" (1997: 225). Japanese marketing experts used the term to define the process by which products of Japanese origin were localized to suit local tastes and interests, and vice versa (Khondker, 2004). Robertson was the first to use this term in the context of social sciences and discussed globalization as "being reflexively reshaped in such a way as to increasingly make projects of glocalization into the constitutive features of contemporary globalization" (1995: 41).

Regarding the issue of globalization of cultures, Nederveen Pieterse discusses three approaches: clash of cultures, single culture, and hybridization (2004). The first is the view that people's cultural and religious identities will be the primary source of conflict in the post-Cold War world (Huntington, 1993). The 'single-culture' approach is the view that a homogenized world is dominated by a single culture that erases local differences. According to the third view - hybridization or synthesis - local needs are adjusted to globalized concepts. Glocalization and hybridization share a common ground on conceptualizing cross-cultural influences, but there is a slight difference. Glocalization explains the interaction between local and global, and the interconnection between local cultures; hybridization, on the other hand, deals with the mixture of different cultures (Nederveen Pieterse, 1993).

With a more cultural orientation, Timothy Taylor defined glocalization as "the extent to which the local and the global are no longer distinct - indeed, they never were - but are inextricably intertwined, with one infiltrating and implicating the other" (2003: 67). Anatolian pop with Turkish folk music instrumentation and repertoire can be interpreted as an example of glocalization. The main influence of Anatolian pop was the Anatolian aşık (lover) tradition of traveling folk musicians who improvised with folk poetry, drawing on the philosophy of Sufism and accompanying themselves on bağlama. ${ }^{8}$ Anatolian pop musicians began to draw on folk literature attributed to famous aşılks (such as Karacaoğlan, Pir Sultan Abdal and Dadaloğlu). Așık Veysel Şatıroğlu (1894-1973), a prominent blind aşı $k$ who was active while the movement was taking root, was the first

\footnotetext{
8 The timbre of bağlama - the Turkish folk lute also known as saz — had a special impact on the sound of Anatolian pop sound.
} 
aşık to gain a wider audience through the media, and his songs were re-recorded by wellknown Anatolian pop artists.

There are many ways in which the influence of Turkish music on musicians was manifested -something we can understand as the result of processes of differentiation. In the case of Turkish musical glocalization, Western music genres, such as rock'n'roll, psychedelic rock, and prog rock, have been intermingled with Anatolian folk music elements and instruments. As the notion of glocalization suggests, any set of sociocultural formations can be adapted to local taste and Anatolian pop represents the adaptation of Western forms into local contexts. Cahit Berkay explains the hybrid musical zeitgeist of the era:

Anatolian pop reflects the Turkish joke that states, "You cannot sell a snail in a Muslim neighborhood"9. If you are making music in this country, you have to know this country is not restricted to Istanbul, Ankara and Izmir. Your music has to be nourished by Anatolia (Akkaya \& Çelik, 2006: 167).

By excluding the cultural and economic centers of the country, Berkay draws on the importance of familiarity in musical taste. If Western popular music had been presented to an Anatolian audience without any attempt at localization of the genre, it probably would not have made an impact, because it sounds quite foreign to a taste accustomed to makam art and modal folk traditions in Turkey.

Bruno Nettl differentiated musical Westernization (imitating specific features and techniques from Western culture in order to introduce non-Western practitioners with Western religious, musical, cultural, or political approaches) from musical modernization (preserving and continuing the tradition rather than changing it, and extending the tradition with the adoption of Western techniques) (1978: 171). Musical Westernization manifested as the copying of Western popular music forms. Aranjman covers that directly imitated French, Italian, or English pop songs adding Turkish lyrics to the original piece - even sometimes purchasing the master output from the studio - stand as a musical reflection of the globalized world. Turkish pop diva Ajda Pekkan, for example, used to sing these songs in broken Turkish with an ersatz English accent to give the impression of a European singer performing it. Westernization was deeply rooted in the cultural

\footnotetext{
${ }^{9}$ A proverb in Turkish denoting that one cannot market a product to an irrelevant audience.
} 
practices of the era, and aggrandization of the West was reflected in the small details of everyday life. A European look and an imitation of a European accent became features of popular music of these years. As in the Aranjman style, transferring the sound of European pop directly to the Turkish music market is linked with homogenization and, as Holton states, "equivalent to Westernization" (2000:142). As we can see in the Aranjman form, Westernization was perceived as an equivalent of modernization.

The glocalization process that occurred in Anatolian pop refers to the juxtaposition of the traditional with the modern, drawing influences from the aşı $k$ tradition and integrating modal melodic sequences of Turkish folk into Western forms. Incorporating local and traditional music forms into Western genres has been a complicated venture ever since the early years of the Turkish Republic. Embracing or rejecting local musical influences in Turkish popular music was a manifestation of complex national identity politics. Nationalism became the main value as regards the construction of the Turkish Republic from the ruins of the Ottoman Empire, and it revisited the cultural agenda of the country in the following decades.

Regarding the deep-rooted effects of this East/West dilemma, DJ and producer Kaan Düzarat comments: "During the Westernization process, the existing culture had rejected with a denigration of being peasant or Eastern. I was born in 1980, and this case of rejection reached even our generation" (as cited in Sarıçam, 2014). Düzarat's comment reveals the particularly complex nature of Westernization in Turkish society. As a DJ performing in my early 20s, I recall hiding my Balkan and Anatolian folk music knowledge inherited from my family among my peers, because those weren't appreciated as 'hip' back in those times. Before the age of internet, performance and a taste of Anatolian folk music were attributed to working-class and rural populations in Turkey. As the dissemination of music changed with the evolving technologies, the class-related connotations of music consumption started to blur.

Artistically, the most prolific era of Turkish popular music occurred between 1960 and 1980, taking the form of glocalization with the experiments of rock'n'roll, psychedelic rock, jazz, disco, and funk. However, this trend came to an abrupt end with the 1980 military coup staged against the supposed rising communist and Islamist influence. The ensuing economic crisis, political oppression, and censorship affected cultural and 
musical life, exacerbated by several imprisonments. As Stokes states: "Anatolian Rock was effectively driven underground by the generals in 1980" (1999: 13). Many left-wing musicians had to keep a low profile, some prosecuted, others leaving the country. For instance, Selda Bağcan, the most prominent international face of Anatolian pop, was taken into custody three times and put on trial nine times for her protest song lyrics (Canbazoğlu, 2009: 227). TRT also applied censorship to musicians such as Selda Bağcan and Cem Karaca.

\section{Local Connotations of Disco in Turkey}

Like many genres of Western popular music, disco also found a place in Turkish popular music. At the end of the 1970s, glocalization of disco music by Turkish musicians occurred with the utilization of long-standing Ottoman/Turkish music forms. Osman İșmen pioneered the Turkish disco with his orchestra combining a funk orchestra consisting of a rhythm and horn section, with Turkish style violins and mey ${ }^{10}$. As an arranger, band leader, and keyboard player, he had a unique approach to combining makam music influences with disco grooves. In 1978, he released Diskomatik Katibim, followed by Disko Madımak in 1979. The latter consisted of arrangements of the up-tempo Turkish folk songs in Oyun Havası form such as 'Madımak', 'Dere Geliyor Dere' (The River Flows River), 'Mevlana' (Rumi). These albums were significant examples of the trend in the Turkish popular music industry: fusion recordings of a specific instrumental Anatolian folk music form called Oyun Havası, which functioned mainly as dance music and often performed in wedding ceremonies or any kind of celebration where traditional dances take place. Earlier in 1973, Esin Engin Orchestra released Modern Oyun Havalarl, followed by the album Modern Fasıl in 1978.

Another significant album of glocalization during the era is Disco Fasll, released in Turkey in 1979 by the Bip!Plak record label, which launched a series of local disco adaptations targeting a popular audience. This LP gathered together the most accomplished Turkish art music performers such as Coşkun Sabah on oud and Halil Karaduman on kanun in an ensemble, İstanbul Çalgıcıları (Instrumentalists of Istanbul), made up of drums, guitar, bass, saxophone, Moog synthesizer, and percussion, and a Turkish vocal group of Turkish

${ }^{10}$ Mey is a double-reed aerophone, common in Turkish folk music. It is similar to the Armenian duduk. 
art music singers, İstanbul Şarkıcıları (Singers of Istanbul). ${ }^{11}$ The Disco Fasıl compilations, the first album from 1979, combined the songs in Oyun Havası form and presented them in a continuous potpori form. The A side contains four up-tempo traditional songs, 'Telgrafin Tellerine Kuşlar mı Konar' (Do the Birds Perch on the Wires of Telegraph), 'Sallasana Sallasana Mendilini' (Wave Your Hankie), 'Karanfilim Budama' (My Clove Is Pruning) and 'Beyoğlu'nda Gezersin' (You Wonder Around Beyoğlu), all melded together with interludes including heavy bass drives, funky rhythms with an intense groove, melodies from the Moog reminiscent of Theremin sound, and flamboyant saxophone solos. These and other features associated with Western disco music are combined with solos on kanun and oud, which are common instruments in Turkish music.

Before exploring the cultural codes inherent in the glocalization of Disco Fasll, another concept - potpori - needs to be explained. Taking its name from the French pot-pourri, potpori is created by assembling together selected parts of songs. For instance, a verse and a chorus from one song might be combined with selected parts from another song. The musical usage of potpori began with the Turkish Radio and Television choir Yurttan Sesler Korosu (Voices from the Homeland), led by Muzaffer Sarıözen in 1947 (Kozanoğlu, 1988: 24). As a way to institutionalize Anatolian folk music, a number of traditional songs collected through field recordings from different regions of Turkey were compiled to create a traditional music treasure trove for the choir. One of the main reasons for the selection of the song hooks in the potpori stems from the efficient presentation of newly collected folk material. Potpori thus represents the continuous performance of folk songs that have similarities in their tonal centers. Despite its folk origins, potpori became a popular concept both in Turkish art music and Turkish popular music.

Potpori is similar to DJ sets and mixtapes in the way in which different musical elements are interlinked and performed in a continuous flow. Indeed, this kind of musical flow is not specific to potpori, but rooted in the Fasil form, which can go on for up to four hours. Fasil, on the other hand, comes from the Ottoman makam music tradition, the artistic musical heritage of the empire that preceded modern-day Turkey and was distinct from Anatolian folk music, reflecting different regional traditions of various ethnic groups. It is

\footnotetext{
${ }^{11}$ Calgıcl means instrumentalist. However, it is important to note that using çalgıcı rather than "musician" has pejorative connotations. Usually, musicians of Romani origin are referred to as çalgıcı. Such usage denotes many things about the inner dynamics of discrimination of minority ethnic groups in Turkey.
} 
the longest form in Ottoman makam music, presenting a combined structure created from several different instrumental forms that are played back to back with a set of rules concerning pitch material, rhythm, and intermediary sections. During the 19th century, the song form was added to Fasıl. So as not to break this continuity, sometimes the taksim (improvised solos) lasts as long as 20-25 minutes to give other instrumentalists and singers a rest during the Fasil set (Eken, 2007: 32). Tracing its roots to the 15th century, the Fasll form witnessed many changes throughout the centuries. The declaration of the Turkish Republic and the ensuing Westernization resulted in an era of rejection of Ottoman makam music, trapping the Fasll performances in the private sphere. The form was revived in the late 20th century, this time with a dance and entertainment function. Recent somewhat misleading interpretations of Fasıl, especially after the 1990s, refer to it as live entertainment by an ensemble performing only the song form in Turkish art music. Just as DJs have developed many techniques, from beat matching to scratching, to maintain a continuous flow of music, so too have Fasıl performers. For instance, in Turkish music, there are structured melodies called Beylik aranağme (common intersecting melodies) connecting the pieces in Fasil.

Another album, 'Ayva Çiçek Açmış' (Quince Tree in Bloom), by the same ensemble İstanbul Şarkıcıları \& Istanbul Çalgıcıları, was released in 1980 and includes an adaptation of a composition by Fikret Kızılok, 'Köroğlu Dağları' (Mountains of Köroğlu).12 This piece reflects direct funk influences with catchy guitar riffs, propulsive string and horn parts, and combines these with Turkish-style violin performance including makam slides and highly ornamented rhythms of the darbuka. ${ }^{13}$ The signature song of the album, 'Ayva Çiçek Açmış', is an anonymous Oyun Havası. ${ }^{14}$ It is in Uşşak makam, which includes the Segah pitch, which is one comma lower than the B when it is notated in the Turkish tuning system, in which D is tuned to 440 hertz. The whole tone in Turkish makam music is divided into nine equal parts; there are four types of sharps and flats in a whole tone, which gives Turkish music its microtonal character. This piece blends Turkish dance music form Oyun Havası with musical elements borrowed from Western disco sounds

\footnotetext{
12 https://www.youtube.com/watch?v=eTe2YErKEno

13 Darbuka is a membranophone common in Turkish music, which is also called doumbek.

14 https://www.youtube.com/watch?v=HWVHJnPvDBg
} 
from the period. While the vocal parts of the piece are an example of Turkish art music, the interludes connecting those combine makam solos with disco features.

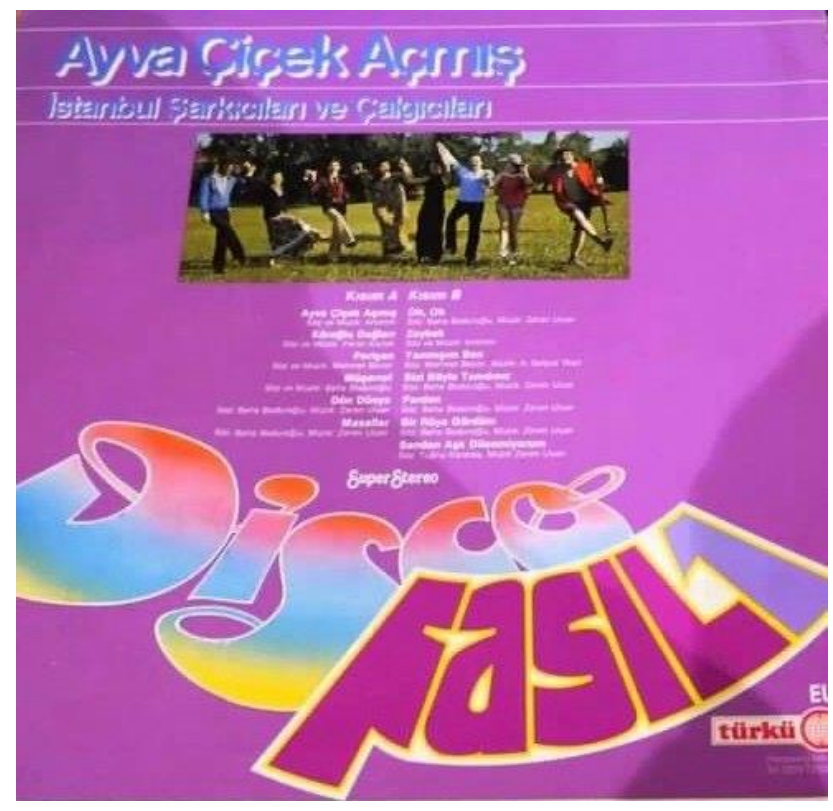

Figure 1. İstanbul Şarkıcıları \& İstanbul Çalgıcıları, Ayva Çiçek Açmış Album Cover (Istanbul Çalgıcıları \& Istanbul Şarkıcıları, 1980).

These albums were produced prior to the authoritarian climate of the September 12, 1980 coup, as during those years, opportunities for live music or dance halls were scarce. They used disco influence to modernize the local forms and targeted a mainstream popular music audience with a commercial orientation. Turkish DJ and producer Sertaç Oğul (As Smooth As) commented on these recordings:

These songs weren't originally composed to be played in discos. During their era, there wasn't a lively disco music culture in Turkey. For the orchestration and arrangement of these songs, the disco genre was imitated, that's all (Sertaç Oğul, personal communication, October 15, 2018).

However, there was another main function those recordings serve: as soundtracks for films. Turkish comedy films of the 1960s-80s tended to use jazz, funk and disco as an accompaniment to chase or comedy scenes. For instance, Zafer Dilek released his version of another Oyun Havası 'Yekte' in 1976, offering a fusion of funky riffs, modal melodies, and traditional Anatolian wooden-spoon playing to create a polyrhythmic structure. This was used in the 1977 movie Sakar Şakir (Clumsy Şakir) starring Turkish comedy star 
Kemal Sunal. Osman İșmen Orchestra's 'Nihavend Longa' from Diskomatik Katibim album is used in another Kemal Sunal movie, Korkusuz Korkak (Fearless Coward).

While Bip!Plak released Turkish interpretations of disco music, another Turkish label, Türküola, released Derdiyoklar's LP as part of their Disco Folk series in Germany. ${ }^{15}$ Turkish popular music in the diaspora, mainly in Germany, resulted in new unique adaptations of Anatolian musical elements. Derdiyoklar was a duo made up of two Turkish immigrants in West Germany who performed at weddings and circumcision feasts and covered traditional Anatolian folk songs with an instrumentation consisting of electro-saz, guitar, drums, and synthesizers. ${ }^{16}$ This record recently gained a cult following in the Turkish alternative music scene and drove a young generation of local musicians to use similar psychedelic themes in their own music. ${ }^{17}$ These recordings remained underground during their release years, then later became popular with reissues during the Turkish psychedelic revival, as videos of the duo playing at wedding ceremonies spread via YouTube. Although the title of the album includes disco, the music of Derdiyoklar offers a fusion of Turkish folk with psychedelic rock.

After the 1980s, the term disco began to mean anything related to dance and Oyun Havası. As it also became a feature of comedy movies with the popularity of Kemal Sunal movies, the albums including 'disco' in their names shared a common commercial interest combining up-tempo Oyun Havası music with comedy features. For instance, Hurşid Yenigün's Disco-Gırgır: Göbekli Dümbelekli recordings define the period's appreciation of disco. These recordings don't reflect any disco or funk music influences, other than the basic dance function of Oyun Havası and potpori forms. Likewise, many recordings labeled as disco, such as Disco Göbek (Disco Belly Dance), Disco Fasıl Rumbada, Karadeniz Disco, Disco Kanto and Oryantal Çiftetelli Disco, were released during the 1980s. ${ }^{18}$ In 1992,

15 Türküola was established in Cologne, Germany, in the late 1960s. The company moved its operations to Turkey in 1973. Also, Uzelli, another record company with its significant releases of Anatolian pop/rock, started in Frankfurt in 1971 and later moved its operations to Turkey.

${ }^{16}$ Saz means instrument in Turkish but is synonymous with the bağlama, since it is the most regularly used instrument in Turkish folk music.

${ }^{17}$ In music, the term psychedelic mainly denotes musical experimentation, particularly in form and timbre. Hindu classical music instruments tabla and sitar were used to evoke a psychedelic experience, as with some of the signature timbres of 1960s new age spirituality. Besides, studio techniques such as filtering, extreme reverb, phasing, extended delay hoops, and multiple repeats were utilized in the recordings to create surreal sounds (Chepkemoi, 2017).

${ }^{18}$ Disco Fasl Rumbada is an album title by Hurşit Yenigün offering an intertwining of rumba and disco music, but these are actually nonsense titles to draw attention to the entertainment concept, not the actual musical influences. Karadeniz Disco means Black Sea region disco, a performance of Oyun Havası with 
Erkan Ocaklı released an album titled Disco Nataşa, which included newly arranged entertainment songs from the Black Sea. ${ }^{19}$

My interviews about the local appreciation of disco revealed yet another dominant usage. The Turkish word disko also represents the physical venue of the dance hall, an abbreviation of discotheque. This time, disko referred to the dance halls in Turkey; this was a widespread usage of the term as an actual space for dancing, instead of a music culture. The first disko in Istanbul, established by Tevfik Dölen and called 'Tefo'nun Yeri' (Tefo's Place), started its operations with an archive of 400 LPs in Siraselviler street of Beyoğlu (Akçura, 2014). The DJ of the venue, Emre Serter, said Charles Aznavour, Adamo, Beatles, and Rolling Stones were among the most frequently played artists and bands (as cited in Akçura, 2014). Following the popularity of the first disko, other venues focusing on the performance of recorded music with DJs - instead of live music performances increased in numbers. In the late 1980s versions of diskos, for instance, synth-pop and new wave became the prominent culture, and the mainstream popular music of the era was labeled as disko müziği (disco music). This dance sub-culture represented the kind of decadent environment, in which an innocent girl could succumb to the effects of alcohol and dancing to disko müziği. Turkish movie stars of the era, such as Hülya Avşar or Yaşar Alptekin, were to be seen dancing in discos to synth pop music and new wave, cementing the links among synth pop and new wave and disco music during the late 1980s.

\section{Reinvention of Turkish Disco}

This section examines the current usage of the term Turkish disco and explains its connections with the genre of Turkish psychedelic. Starting with the impact of the political atmosphere on the subject, after the 1980 military coup, Anatolian pop experienced a dramatic decline. Recordings from the 1970s lost their value under the political and cultural oppression, while others were forgotten, abandoned in moldy basements. Thanks to the nostalgic interest in bringing local music back to the scene, and the revival of vinyl culture, Turkish popular music from the 1970s has been resurrected in the new millennium, creating new spaces for performance. Not only global, but also

\footnotetext{
kemençe (a bowed string instrument common in traditional Black Sea reginal music), also reflecting the entertainment function. Disco Kanto is an album by kanto singer Nurhan Demircioğlu. Oryantal Çiftetelli Disco combines Oriental dance with the Oyun Havası form Ciftetelli.

${ }^{19}$ Natasha is a pejorative term for a Russian woman living in the Black Sea region.
} 
Turkish listeners began to rediscover many inspiring pop albums of the 1970s. ${ }^{20}$ Many of the Anatolian pop records were rediscovered by record diggers and reappeared in Turkish psychedelic and Turkish disco compilations in the past decade or so. During that process, Anatolian pop acquired a new label in the global music market: 'Turkish psychedelic'.

The term was created overseas and retroactively came to be used in Turkey. Güven Erkin Erkal was the first Turkish music writer to adopt the term in his book, The History of Rock in Turkey 1: Psychedelic Years (2013). Prior to this, music writers and musicologists referred to this time as the era of Anatolian pop. A recent book, The Turkish Psychedelic Music Explosion: Anadolu Psych 1965-1980, by Daniel Spicer, follows a more biographical approach to the genre with chapters on stars such as Selda Bağcan and Moğollar.

The first use of the term Turkish psychedelic to define a compilation was "Love, Peace \& Poetry - Turkish Psychedelic Music" released in 2003, which included an eclectic group of musicians such as Selda Bağcan, Bülent Ortaçgil, Erol Büyükburç, and Özdemir Erdoğan. On the other hand, in the vinyl catalogue 1001 Record Collector Dreams, which was published in 1998 by Hans Pokora and lists rare and valuable records, Erkin Koray's Elektronik Türküler (1974) is labeled as progressive, his Same (1973) as psychedelic/folk/progressive and Ersen's album Dünden Bugüne (1975) is labeled as folk/progressive. Cornelia \& Holger Lund claims that the revival of Turkish rock and funk music began in 2006 with hip-hop producer Egon's compilation Stones Throw Podcast \#12: Turkish Funk Mix, which contributed to the international interest in the genre (2015: 178).

The rise of Turkish psychedelic music owes itself to the activities of several significant DJs and producers. Roskow Kretschmann of the German DJ/producer collective Jazzanova, who frequently traveled to Turkey and collected local records, released in 2005 a two-compilation series called Bosphorus Bridges. DJ Kaan Düzarat states that "the scene clearly changed after that" (Kaan Düzarat, personal communication, October 10, 2018). In 2006, Mustafa Özkent's Gençlik ile Elele album, a local funk-ish gem of the 1970s, was re-released by another eminent global digger, Andy Votel's UK record label Finders

\footnotetext{
20 The movie Issiz Adam (Man Alone) from 2008 was crucial in attracting a mainstream audience to the joys
} of record collecting with a main character who was fond of 1970s Turkish recordings. 
Keepers. In 2007, American hip-hop producer Oh No released the album Dr. No's Oxperiment, which heavily sampled from Anadolu Pop recordings, with the first track on the album sampling Selda Bağcan's song 'İnce Ínce' (Skoog, 2012: 241). Two years later, rapper Mos Def discovered the same album and used Selda Bağcan's vocals in his 'Supermagic' track.

On the local scale, Turkish DJ and record collector Barıș K was among the first to see upcoming localization trends in the popular music industry. He started editing Turkish songs as early as 2005 and released a mixtape, Eurasia, in 2007, bringing edits of Anatolian pop gems in a mix together. His flux of edits and compilations made the Anatolian pop visible, and this trend was followed by a niche crew of Turkish DJs and remixers such as Kaan Düzarat, Hey Douglas, Kozmonoz Osman, Jonny Rock, and Discolog. Many of the songs edited by those DJs were selected from the original LPs and singles recorded in the 1970s, which, until the new millennium, were referred to as Anatolian pop. Those edits and remixes gained the new global label 'Turkish disco' in the 2010s.

The impact of Turkish popular music of the 1970s was felt again in the 2010s with its rising popularity among deep house and disco DJs and producers. The term 'Turkish disco' was created as a label to market groovy recordings and the upbeat Anatolian pop in the global music industry, especially the remixes of Turkish popular music from the 1970s. At the 2017 Burning Man Festival, DJ Oliver Koletzki played Turkish pop singer Neșe Karaböcek's version of 'Çayelinden Öteye' (Further from Çayeli) in his set, and the crowd danced up a storm. ${ }^{21}$ This traditional song from the Black Sea region of Turkey was covered by Karaböcek during the Anatolian pop era and was recently edited by Norwegian producer Todd Terje under the title 'Yali Yali' using disco beats.

Turkish DJs and producers, such as Barış K, Kaan Düzarat, Hey Douglas, İpek İpekçioğlu, Fattish, Kozmonot Osman, and Discolog took leading roles in editing such local repertoire as part of their artistic pursuits. Followed by a younger generation of DJs of Turkish origin including As Smooth As (Sertaç Oğul), Mehmet Aslan and Cheesebrothers, the mixtapes of Anatolian pop gained global visibility. Ricardo Villalobos remixed the track 'Kime $\mathrm{Ne}^{\prime}$ (None of their Business) by Turkish psychedelic band Insanlar (with Barış K on beats, Alican Tezer on drums and Cem Ylldız on electro-saz). The tracks selected by local or

21 https://www.youtube.com/watch?v=Fv451fZN904 
foreign DJs are stylistically diverse and range from Arabesk ${ }^{22}$ and jazz to pop and prog rock. ${ }^{23}$ The use of electro-saz (electric bağlama) is also quite common.

The first global usage of the term was in 2012 in an album called Turkish Disco Folk released by Arşivplak company, including two edits by Volga Çoban. He stated that "The vinyl didn't create much of attention after its release, but eight months after someone shared some tracks on YouTube there was a sudden increase in the sales, and now the album is in its third release" (Volga Çoban, personal communication, November 19, 2019). For instance, one of the tracks included in the album is 'Volga Nehri' (Volga River), which samples the 1980 recording by İstanbul Şarkıcıları's Ayva Çiçek Açmış. ${ }^{24}$ 'Volga Nehri' is 09:56 minutes long and completely edited from the material taken from the instrumental parts of the songs included in the Ayva Çiçek Açmış album. The piece starts with a catchy opening guitar riff, which is a section from the song 'Ayva Çiçek Açmış,' starting at 01:46. ${ }^{25}$ The part of 'Volga Nehri' that starts at 0:18 is the opening keyboard solo of 'Köroğlu Dağları,' followed by a G clarinet solo in Uşşak makam. In the same album, there is also a version of 'Ayva Çiçek Açmış,' which is 1:40 minutes long. Volga Çoban preferred to cut the vocal parts of the piece which contains direct Oyun Havası influence; instead, he used the interludes of funk and disco. However, the main melody of the piece starting at 00:09 is performed with electro-saz in Uş̧sak makam, which gives the piece its microtonal character.

Volga Çoban utilized the musical material from one of the primary works of glocalized disco in Turkey and later used that material to create a new form. He defines himself as a vinyl collector and dealer. He bought the copyright of the piece for a re-release from the producer Baha Boduroğlu. However, in the Turkish Disco Folk album, İstanbul Şarkıcıları was not listed as a performer, nor was Volga Çoban acknowledged as the producer. The album mainly highlights the title: Turkish disco.

\footnotetext{
22 The genre of popular music emerged in the late 1960s in Turkey, bringing Arabic and Egyptian music influences with freer forms of Turkish art/folk music. The Turkish cultural elite tended to degrade Arabesk as the musical and cultural consequence of urban migration from rural towns in the 1960s, and it was forbidden on Turkish Radio and Television during the 1970s for being the 'low' culture of slums (see Stokes, 1989).

${ }^{23}$ Tracks by artists such as Barış Manço, Erkin Koray, Selda Bağcan, Neşe Karaböcek, Edip Akbayram, Gülden Karaböcek, Ali Riza Binboğa, Osman İsmen Orchestra, Derdiyoklar, Nazan Öncel, Nil Burak, Seyyal Taner, Ferdi Özbeğen, Mehmet Pekün, Füsun Önal, Ajda Pekkan, Hakkı Bulut, Özdemir Erdoğan and others. ${ }^{24}$ https://www.youtube.com/watch?v=LV9Wyw7By7A

25 https://www.youtube.com/watch?v=HWVHJnPvDBg
} 
The recent usage of Turkish disco, however, is closely linked to commercial interests. The house and disco remixes of Turkish popular music gave standardized form to the culture in the form of electronic dance music. In recent times, what has been referred to as Turkish disco is being played in electronic music clubs, festivals, on the radio, and in any kind of setting fostering dance. Producer and DJ Mehmet Aslan, who makes Turkish disco edits, regularly tours in Europe, and plays Turkish psychedelic pieces in his DJ sets, explains the attention on Turkish popular music as follows:

Turkish music's popularity in an industry which regularly looks backwards is quite normal, because the 1960s and 70s' music culture in Turkey was quite rich. We can reach music all around the World with the influence of globalization and internet. People want to find 'exotic' music, they get bored of the music of the Western world (Mehmet Aslan, personal communication, October 11, 2018).

The terms 'Turkish disco' and 'Turkish psychedelic' are closely interrelated - they are used to define the Turkish popular music of the 1970s. Through a discography analysis, it can be concluded that Turkish psychedelic became an umbrella term to describe the fusion of Western popular music (including psychedelic rock, funk, jazz, soul, pop) with Anatolian folk influences. Besides Anatolian pop, also Arabesk recordings can be included under the tag of the genre. Recent adaptations of Anatolian pop by the bands currently performing are observed to be classified under the same title. Some common musical features of the category may include the use of the Turkish/Anatolian traditional music repertoire, tingling guitar sounds, utilization of electric bağlama, kanun, oud, G-clarinet, and Moog synthesizers, and the employment of melodic phrases common in Anatolian folk music. The term developed to be used commercially to promote Turkish popular music, and some exaggerated conceptions of 'Turkishness' took place on album covers, with 'exotic' Oriental images becoming a feature of promotion. 


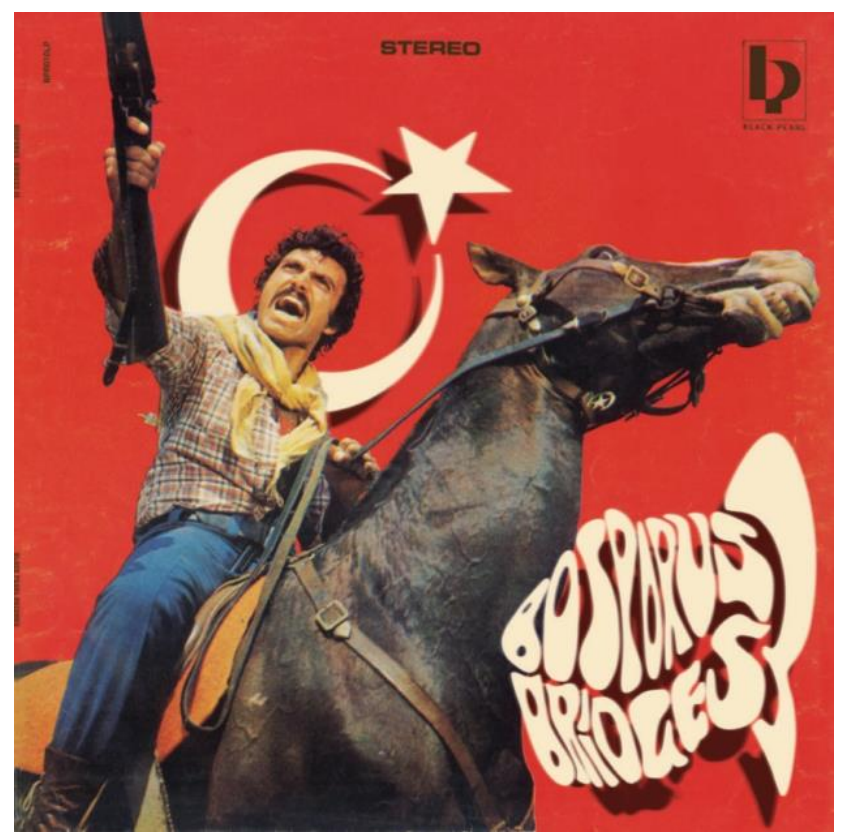

Figure 2. Bosporus Bridges Volume 3, album cover (Bosphorus Bridges 3, 2009).

Another reason that the Anatolian pop movement, and the local adaptations of the funk and jazz from Turkey have been presented as Turkish psychedelic, might be the spiritual connection of the word 'psychedelia'. Psychedelia refers to drug-related connotations and the expansion of the consciousness through substances. Such a pursuit of expansion of consciousness through the consumption of LSD was not the case in 1970s music culture in Turkey. Some individual experimentation probably took place, but that was not at all at the core of the musical culture. However, the 1960s also marked an increase in attention to Eastern philosophies, mainly centering on Indian traditions. The Turkish folk tradition has strong roots in Anatolian Sufism through the aşı k tradition, which might also contribute to the myriad meanings for the word 'psychedelia'. Drummer and multiinstrumentalist Orçun Baştürk states:

Some people even call Oyun Havası or Oriental dances as Turkish psychedelic. This is a marketing technique. For me psychedelic means playing with the timbre to make it feel more ethereal (Orçun Baştürk, personal communication, November 15, 2019).

The word psychedelic lost its actual meaning in that commercialization process. Of course, that movement resulted in positive outcomes benefiting local musicians. As a consequence of this growing attention to the Turkish popular music of the 1970s, Anatolian pop stars such as Selda Bağcan, Barış Manço, and Moğollar gained global 
visibility and popularity, resulting in re-issues of many of their recordings. Anatolian pop protest singer Selda Bağcan became a global star who performed at the 2016 Primavera Festival in Barcelona, increasing the popularity of the genre in Europe. Also, new alternative bands and musicians began using Anatolian pop influences: among them, Babazula and Gaye Su Akyol, which regularly perform in Europe. Australian psychedelic rockers King Lizard and the Gizzard Wizard, or the Netherlands-based Altın Gün began to imitate 1970 s Anatolian pop.

\section{Conclusion}

The first wave of Turkish disco music in the late 1970s featured timbral varieties of synthesizers, funky riffs, and four-on-the-floor dance rhythms, utilized in order to Westernize local music forms such as Oyun Havası. Beat matching and mixing techniques that kept the music on the dance floor were the main reasons for the later evolution of DJ culture. Such a feature, however, had already localized in Turkey in the 1970s through the use of potpori in recordings, connecting the hooks of songs via interludes of funk and disco music. With the 1980 military coup, not only the political, but the cultural and musical climate in the country changed dramatically. The common ground was the function of the music, and disco started to denote a 'decadent' form of entertainment. For a brief time in the late 1970s, creative combos of disco and potpori forms were made, until the military coup of 1980 introduced changes that affected popular music. After the 1980s, the term 'disco' started to be used for virtually any recording that promoted dance, regardless of its stylistic features. What was left was not the style, just the function of inducing a drive to dance. What makes disco Turkish is not its national or ethnic origin, but the Turkish music influence that can be observed in the glocalized recordings of the 1970s.

Recent years have witnessed the huge impact of Turkish popular music on the global music market. Whether it is the 'exotic' Oriental image of Turkey that draws such attention to Turkish popular music, or personal DJ quests to discover lesser-known musical regions, the impact of the movement resulted in a flourishing music scene through newly forming acts, reissue releases, and a revival of those groups and musicians. The Anatolian pop movement of the 1970s became popular in Europe and the United States like no other Turkish musical movement before. What had previously been called 
Anatolian pop was renamed Turkish psychedelic, and its popularity rose thanks to local and foreign DJs keen to bring local music cultures back to the popular music scene.

At the end of the 1970s, disco became a tool of musical modernization in Turkey through a reevaluation of local music forms such as Oyun Havası and potpori. During the 2010s, as a consequence of the rising wave of Turkish psychedelic, Turkish disco also gained a new musical flavor. The recent representation of the term suggests any edit or remix of a Turkish popular music from the Anatolian pop era. Thus, regardless of the source, the edits and remixes of Turkish traditional songs or repertoire influenced by, for instance, psychedelic rock, funk, soul, progressive rock, or jazz from the 1970s can be defined as Turkish disco. While Turkey's first encounter with disco was an example of glocalization by representing funk/disco elements through local forms, the contemporary use of the term suggests any kind of Turkish music that has been adapted to a globalized taste with house/disco beats.

In an era of hybridized musical forms, the local and global usages of the term 'Turkish disco' reveal how local music cultures have been utilized as a form of differentiation in the popular music industry. Power dynamics between cultures and the act of benefiting from a position of privilege while appropriating diverse musical cultures, as well as the way the meaning transforms in the process of music marketing, have been the risky aspects of the concept. Both terms - 'Turkish psychedelic' and 'Turkish disco' - initially started to circulate in Europe and the USA and have been targeted to promote these genres to a Western audience; in turn, they have also started to be utilized in Turkish popular music press. Glocalization of disco music in Turkey adapted traditional forms to a modernized taste, while the reinvention of Turkish disco made the significant repertoire of 1970s Turkish popular music visible on the global music market and created fresh performance spheres for that culture.

\section{REFERENCES}

Akçura, Gökhan. (2014, 23 December). "İlk Diskolar”. (First Discos). Bodruma Geldik. (We came to Bodrum) Retrieved from:

http://www.bodrumageldik.com/mobil/hdetay.php?newsid=21210 
Akkaya, Ayhan; Çelik, Fehmiye. (2006). “Cahit Berkay ile söyleşi.” (Interview with Cahit Berkay.) 60'lardan 70'lere 45'lik Şarkılar. (45 Singles from 60's to 70's.) Ed. Ayhan Akkaya and Fehmiye Çelik: pp. 167-168. İstanbul: BGST Yayınları.

Aksoy, Bülent. (1985). “Tanzimat'tan Cumhuriyet'e Musiki ve Batılılaşma (Music and westernization from the Tanzimat to the Republic). Tanzimat'tan Cumhuriyet'e Türkiye Ansiklopedisi. Istanbul: İletişim.

Alexandrov, Vladimir. (2013). The Black Russian. New York: Atlantic Monthly Press.

Bosphorus Bridges 3. (2009). Bosphorus Bridges 3. Turkey: Black Pearl Records. Retrieved from https://blackpearlrecords.bandcamp.com/album/bosporus-bridges-vol-3

Canbazoğlu, Cumhur. (2009). Kentin Türküsü: Anadolu Pop-Rock. (The Folk Song of the City). İstanbul: Pan Yayıncılık.

Eken, Fikret Merve. (2017). “19. Yüzyıldan Günümüze İstanbul Eğlence Hayatında Fasıl”. (Fasll in the Entertainment Life from 19 $19^{\text {th }}$ Century to Recent Times). MA thesis. İstanbul Technical University, İstanbul: Turkey

Erkal, Güven Erkin. (2013). Türkiye Rock Tarihi 1: Saykodelik Yıllar. (The History of Rock in Turkey 1: Psychedelic Years). İstanbul: Esen Kitap.

Holton, Robert. (2000). “Globalization's Cultural Consequences.” Annals of the American Academy of Political and Social Science, Dimensions of Globalization. 570: 140-152.

Huntington, Samuel. P. (1993). “The Clash of Civilizations?” Foreign Affairs. 72(3): 22-49. İstanbul Çalgıcıları \& İstanbul Şarkıcıları. (1980). Ayva Çiçek Açmış. (Quince Tree in Bloom) [LP]. Germany: Türküola. Retrieved https://www.discogs.com/release/7164691-İstanbul-Şarkıcıları-Ve-Calgıcıları-Ayva-

\section{Cicçek-Açmiș-}

Kadığlu, Ayșe. (1996). "The Paradox of Turkish Nationalism and the Construction of Official Identity" Middle Eastern Studies. 32(2): 177-93.

Khondker, Habibul Haque. H. (2004). “Glocalization as Globalization: Evolution of a Sociological Concept." Bangladesh e-Journal of Sociology. 1(2): 1-9. 
Kozanoğlu, Cevdet. (1988). Radyo Hatıralarım. (My Radio Memories) Ankara: TRT Müzik Dairesi Yayınları.

Lund, Cornelia and Lund, Holger. (2015). "Style and Society - Istanbul's Music Scene in the 1960s and 1970s: Musical Hybridism, The Gazino, and Social Tolerance." Speaking in Tongues: Pop lokal global, Ed. Dietrich Helms and Thomas Phleps. Retrieved from http://geb.uni-

giessen.de/geb/volltexte/2017/12973/pdf/Popularmusikforschung42 11 Lund.pdf

Mimaroğlu, İlhan. (1958). Caz Sanatı. (The Jazz Art.) İstanbul: Yenilik Yayınları.

Nederveen Pieterse, Jan. (1993). “Globalization as hybridization”. Sociology of Globalization: Cultures, Economies, and Politics, Ed. Keri E. Iyall Smith: pp. 39-60. Boulder: Westview Press.

Nederveen Pieterse, Jan. (2004). Globalization and Culture. Maryland: Rowman and Littlefield.

Nettl, Bruno. (1978). Eight Urban Musical Cultures: Tradition and Change. Illinois: University of Illinois Press.

Reynolds, Simon. (2011). Retromania: Pop Culture's Addiction to Its Own Past. New York: Faber and Faber, Inc.

Richter, Felix. (2014). "The Surprising Comeback of Vinyl Records". Statista. https://www.statista.com/chart/1465/vinyl-lp-sales-in-the-us/.

Robertson, Roland. (1995). “Glocalization: Time-Space and Homogeneity-Heterogeneity”. Global Modernities, Ed. Mike Featherstone, Scott Lash, and Roland Robertson: pp.25-44. London: Sage Publications.

Robertson, Roland. (1997). “Comments on the 'Global Triad' and 'Glocalization'”. Globalization and Indigenous Culture, Ed. Inoue Nobutaka: pp. 2017-2025. Tokyo: Institute for Japanese Culture and Classics, Kokugakuin University. 
Sarıçam, Özge Mine. (2014, July 19). “Utanmayın, piste gelin!” (Don’t be shy, come to the dance floor!) Habertürk. Retrieved from https://www.haberturk.com/kultursanat/haber/904259-utanmayin-piste-gelin.

Skoog, Gabriel. (2012). “On Strange Shepherds, Golden Microphones, and Electric Guitars:

Genre, Scene, and the Rise of Anadolu Pop in the Republic of Turkey." PhD dissertation, University of Washington. Washington: USA.

Spicer, Daniel. (2017). The Turkish Psychedelic Music Explosion: Anadolu Psych 1965-1980. London: Repeater Books.

Stokes, Martin. (1989). "Music, Fate and State: Turkey's Arabesk Debate”. Middle East Report. 160: 27-30.

Stokes, Martin. (1999). “Turkish Urban Popular Music.” Middle East Studies Association of North America. 33(1): 10-15.

Taylor, Timothy D. (2003). “A Riddle Wrapped in a Mystery: Transnational Music Sampling and Enigma's 'Return to Innocence'”. Music and Technoculture, Ed. Rene T. A. Lysloff and Jr. Leslie C. Gay: pp. 64-92. Connecticut: Wesleyan University Press.

Tekelioğlu, Orhan. (1996). "The Rise of a Spontaneous Synthesis: The Historical Background of Turkish Popular Music." Middle Eastern Studies. 32(2): 194-215.

Uyar, Yaprak Melike; Karahasanoğlu, Songül. (2016). “The Early Performance of Jazz Music in Turkey" Porte Akademik: Journal of Music \& Dance Studies. 13: 129-139.

Woodall, Carol. (2008). Sensing the City: Sound, Movement, and the Night in 1920s Istanbul (Doctoral dissertation), New York University. Retrieved from: http://www.proquest.com/products-services/dissertations/

\section{DISCOGRAPHY}

Barış K. (2007). Eurasia, Disco Hamam, Turkey. [EP]. 
Bosporus Bridges: A Wide Selection of Turkish Jazz and Funk 1968-1978. (2005). [LP]. Germany: Twimo Records.

Bosporus Bridges Volume 3. (2019). [LP] Germany: Black Pearl Records.

Derdiyoklar. (1984). Disco-Folk. [LP]. Germany: Türküola.

Erkin Koray Dörtlüsü (1968), Çiçek Dağı/Meçhul. [45 RPM]. Turkey: Hürriyet Gazetesi Altın Mikrofon Serisi.

Erol Pekcan, Tuna Ötenel, Kudret Öztoprak. (1978). Jazz Semai. [LP]. Turkey: EMI.

Gencer, İlham. (1961). Bak Bir Varmış bir Yokmuş/ Deniz Ne Kadar Güzel. [45 RPM]. Turkey: Odeon, Turkey.

German, Tülay. (1964). Burçak Tarlası/Mecnunum Leylamı Gördüm. [45 RPM]. Turkey: Ezgi Plakları.

Hurşid Yenigün Orkestra Saz ve Vokal Grubu. (1982). Disco-Grrgır: Göbekli Dümbelekli. [Tape Cassette]. Turkey: Yenigün.

İstanbul Çalgıcıları \& İstanbul Şarkıcıları. (1979). Disco Fasıl 1. [LP]. Turkey: Bip!Plak. İstanbul Çalgıcıları \& İstanbul Şarkıcıları. (1980). Ayva Çiçek Açmış. [LP]. Turkey: Bip! Plak.

Kızılok, Fikret. (1969). Uzun İnce Bir Yoldayım/Benim Aşkım Beni Geçti. [45 RPM]. Turkey: Sayan Plak.

Kızılok, Fikret. (1979). Sözle Sazım/Güzel Ne Güzel Olmuşsun. [45 RPM]. Turkey: Sayan Plak.

Koray, Erkin. (1974). Elektronik Türküler. [LP]. Turkey: Doğan Plak.

Moğollar. (1970). Dağ ve Çocuk/İmece. [45 RPM]. Turkey: Disko Alameti Farika.

Mos Def. (2009). The Ecstatic. [CD]. LA: Downtown. 
Mustafa Özkent ve Orkestrası. (2006). Gençlik ile Elele. [LP]. UK: Finders Keepers Records. (Evren Plakları, Turkey, 1973).

Ocaklı, Erkan. (1992), Disco Nataşa. [Tape Cassette]. Turkey: Özfon.

Öngür, Taner \& 43,75. (2018). Sayko Ana. [Digital Album]. Istanbul: Tantana Records. Retrieved from: https://tanerongur.bandcamp.com/album/sayko-ana

Selda Bağcan and Moğollar. (2015). Türkülerimiz. [CD]. Turkey: Majör Müzik. (Original LP 1971).

Selda Bağcan. (1971). Katip Arzuhalim Yaz Yare Böyle/ Mapushanede Mermerden Direk. [45 RPM]. Turkey: Sel Plak.

Turkish Disco Folk. (2012) [LP]. Turkey: Arşivplak. 